\title{
Self-efficacy or context dependency?: Exploring teachers' perceptions of and attitudes towards technology education
}

\author{
Charlotta Nordlöf $^{1}$ (D) Jonas Hallström ${ }^{1}$ (D) Gunnar E. Höst ${ }^{2}$ (D)
}

Accepted: 1 November 2017/Published online: 2 December 2017

(C) The Author(s) 2017. This article is an open access publication

\begin{abstract}
Educational research on attitudes shows that both teaching and student learning are affected by the attitudes of the teacher. The aim of this study is to examine technology teachers' perceptions of and attitudes towards teaching technology in Swedish compulsory schools, focusing on teachers' perceived control. The following research question is posed: How do the teachers perceive self-efficacy and context dependency in teaching technology? Qualitative interviews were performed with 10 technology teachers in the compulsory school (ages 7-16), and the data was analysed using thematic analysis. Based on an attitude framework, three sub-themes of self-efficacy were found: experience, education and interest, subject knowledge, and preparation. Furthermore, four sub-themes of context dependency were found; collegial support, syllabus, resources and status. The results show that, according to the teachers in this study, self-efficacy mainly comes from experience, education and interest. Moreover, contextual factors can both limit and boost the teachers, but overall there are negative attitudes because of a lack of support and resources, which impedes the teaching. Teachers educated in technology education generally express more positive attitudes and thus seem to have advantages in relation to technology teaching, but still they sometimes express negative attitudes in the field of perceived control. Some implications of this study are that it is necessary to promote teacher education in technology and to reserve resources for technology education in schools, thereby supporting teachers in controlling contextual and internal factors that affect their teaching. This support to teachers is especially important if there is an intention for the subject to develop in new directions.
\end{abstract}

Charlotta Nordlöf

charlotta.nordlof@liu.se

Jonas Hallström

jonas.hallstrom@liu.se

Gunnar E. Höst

gunnar.host@liu.se

1 Department of Social and Welfare Studies, Linköping University, 60174 Norrköping, Sweden

2 Department of Science and Technology, Linköping University, 60174 Norrköping, Sweden 
Keywords Technology education - Technology teachers · Attitudes · Self-efficacy · Context dependency

\section{Introduction}

In technology education, teachers' attitudes to technology and technology teaching are considered to be an aspect of teachers' professional knowledge, and teachers' attitudes affect students' attitudes (Rohaan et al. 2008). In other fields, e.g. science education, research shows that teaching is affected by the attitudes of the teacher, e.g. good teaching is characterised by teachers being enthusiastic about their subject and thus the teacher variable is the most important factor determining student attitude (Osborne et al. 2003). A central way of improving science and technology teaching, therefore, is to consider teachers' attitudes (Korur et al. 2016).

In the field of technology education, studies have been done on different aspects of teachers' attitudes, such as self-efficacy and confidence. A previous Swedish study of technology teachers' self-efficacy on assessment shows that teachers with subject-specific education in technology have higher self-efficacy than teachers without subject-specific education (Hartell et al. 2015). A high degree of self-efficacy among teachers also has a positive impact on student achievement (Tschannen-Moran et al. 1998). A Scottish study by Holroyd and Harlen (1996) shows that the participating teachers are less confident in teaching technology (and science) than most other subjects. Nordlöf et al. (2017) show that technology teachers have different attitudes to their subject, and that predictors such as teacher education, in-service training and how the subject is prioritised at the school are central for having a positive attitude. Nevertheless, there is still a lack of research on many aspects of attitude when it comes to teachers and technology education.

There are a multitude of definitions and models of the concept of attitude, but "there is general agreement that attitude represents a summary evaluation of a psychological object captured in such attribute dimensions as good-bad, harmful-beneficial, pleasant-unpleasant, and likeable-dislikeable" (Ajzen 2001, p. 28). However, attitude is not a unidimensional concept, but a complex mix of explicit and implicit sub-components, depending on factors such as old habits and context (Ajzen 2001).

van Aalderen-Smeets et al. (2012) present a theoretical framework for teachers' attitudes, based on a review of previous studies in science and technology education but developed for primary science teachers (van Aalderen-Smeets et al. 2012). There is no similar framework for teachers' attitudes towards technology; therefore, this framework will be tried out in this study when we look at attitudes among technology teachers. It is important to view technology as a subject in its own right, but there are nevertheless important connections between science and technology education, for example, in STEMeducation. Furthermore, in Sweden, science and technology are sometimes studied together in teacher education, and in compulsory school the same teacher often teaches both science and technology. Most important, however, is that the components of this model are of such a general nature in relation to teaching that the model could be construed as relevant not only to science teachers but also to technology teachers (and even teachers in other subjects).

The theoretical framework for primary teachers' attitudes towards science consists of three components; cognitive beliefs, affective states and perceived control, and each component includes two or three elements. Behaviour is seen as something conceptually different than attitude, and is therefore not a part of the attitude itself as is often the case in 
other attitude models (e.g. Breckler 1984). Attitudes are seen as antecedents of behavioural intention, and behavioural intention is seen as a predictor of behaviour in combination with certain circumstances (van Aalderen-Smeets et al. 2012). However, perceived control is a component of the model, including self-efficacy and context dependency. The component perceived control concerns the teacher's perception of having control over both external and internal factors influencing teaching; factors such as collegial support, teaching time and materials, as well as feelings of personal capability and security/insecurity. The theoretical framework, which has been used also in other attitude studies such as Korur et al. (2016) and Nordlöf et al. (2017), is presented in Fig. 1. Since the framework was first developed in a group of science and technology teachers (Asma et al. 2011), we now want to explore the use of the framework in technology education.

In the framework, context dependency is an element of the component perceived control. This element refers to the teachers' belief that external factors affect their teaching by making it easier or harder. The perceived influence of context factors has previously been investigated, e.g. by Lumpe et al. (2000), showing fairly positive context beliefs and also that teaching experience correlates to context belief. In a focus group study of teachers' attitudes towards science and technology, it is shown that perceived control is one aspect of teacher's overall attitude towards these subjects (Asma et al. 2011). Context factors were found to be important in that study, and were seen as something different from other cognitive attitude components. In this study, context dependency is seen as a part of the teacher's attitude towards technology and technology teaching, as an element of perceived control.

The second element of perceived control in the framework is self-efficacy. Self-efficacy is a person's own belief in their own efficacy, and could be described as a judgement of

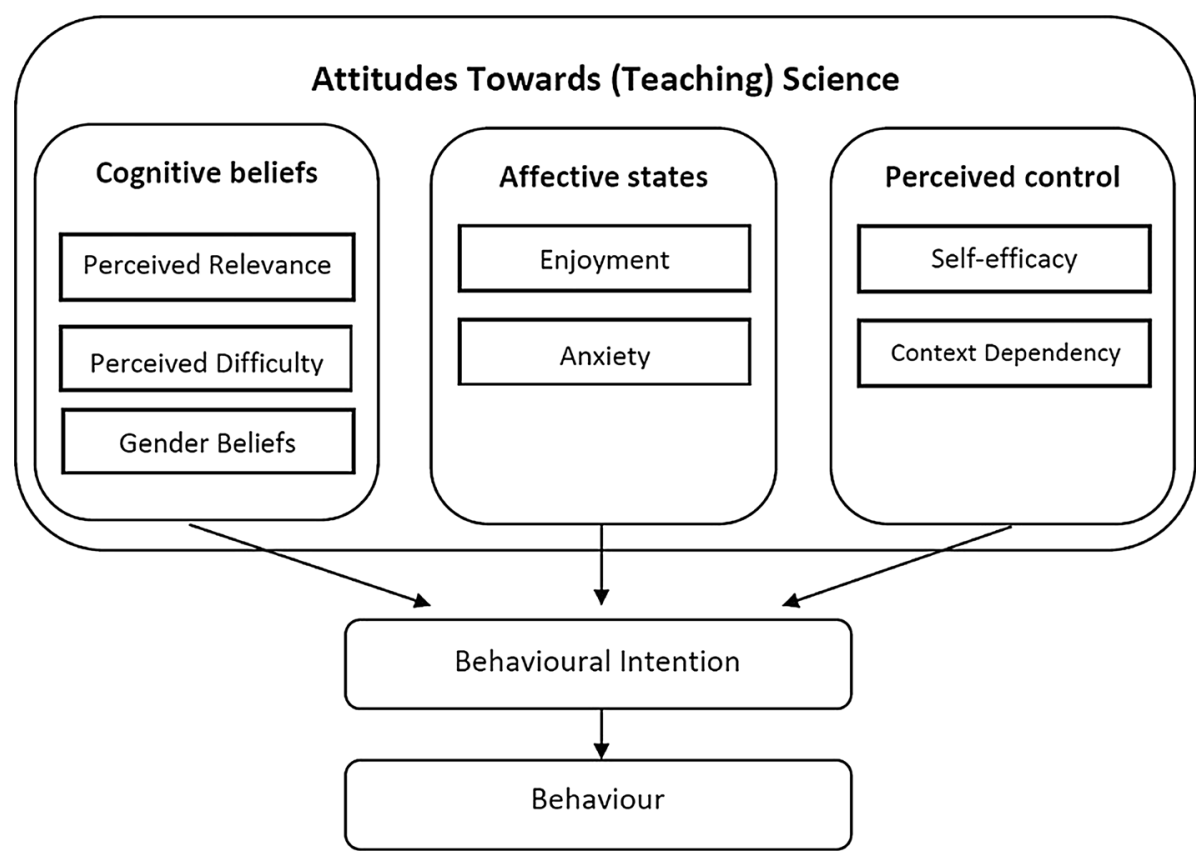

Fig. 1 Theoretical framework for primary teachers' attitudes towards science (Figure originally from van Aalderen-Smeets et al. (2012)) 
one's own personal ability to teach (Bandura 1997). According to Bandura (1997) people's belief in their self-efficacy influences the amount of effort they put into an action and the direction of the actions they conduct. van Aalderen-Smeets et al. (2012) describe selfefficacy as a part of the teacher's attitude towards science, and that it is concerned with individuals' beliefs about their capability of teaching science. In this study, self-efficacy is assumed to be a part of the teacher's attitude towards technology and technology teaching, and it is seen as the second element of the component perceived control.

In a previous article concerning technology teachers' attitudes, the most important predictors for having a particular attitude concerned the teachers' background and the school context (Nordlöf et al. 2017, p. 18), which is why we want to examine the perceived control aspect of attitudes further. The aim of this study, therefore, is to examine technology teachers' perceptions of and attitudes towards teaching technology in Swedish compulsory schools, focusing on teachers' perceived control. The research question of this study is: How do the teachers perceive self-efficacy and context dependency in teaching technology?

\section{Method}

\section{Participants and context}

In Sweden, to teach requires a degree in education. Subsequently, after becoming qualified, you apply to become certified based on your degree in education. You get qualified to teach the subject of technology after completing a teacher education programme that includes technology. The amount of technology included in teacher education varies among universities and year of examination, and depends on what grade you are going to teach. If you have a degree in education that includes technology you are qualified for the certification, but you can also get it by having long teaching experience -8 years or more. This means that certified technology teachers may not have any education in technology at all. In the year of 2015/16 the percentage of certified teachers who taught technology in compulsory school was approximately 44\% (Skolverket 2017). This is one of the lowest percentages among all teacher categories. In grades 1-3 the percentage of certified technology teachers was the lowest (38\%), and in grade 7-9 it was the highest (61\%). In total approximately 22 000 teachers taught technology in Sweden in 2015/16, and scarcely 10,000 of them were qualified (Skolverket 2017). The schools decide themselves how technology education is going to be carried out, but it is common to teach it extensively in school years 7-9. Technology education mainly focuses on technological literacy and includes both practical and theoretical components. In 2011 the current Swedish technology curriculum was introduced, and the core content includes three areas: Technological solutions, Working methods for developing technological solutions, and Technology, man, society and environment. For grades 1-3, 4-6 and 7-9, specific core content is defined. Example of these areas are: Technological solutions that contain common materials and mechanisms with a focus on everyday life (1-3); electrical circuits and simple technological systems (4-6); and basic electronics, digital technology, control systems, manufacturing and properties of materials (7-9) (Skolverket 2011).

To answer the research question, an interview-based qualitative research approach was chosen. The study was therefore based on interviews with ten Swedish technology teachers. About 30 teachers were asked to participate in the study. Ten agreed to be 
interviewed. The informants had different backgrounds (e.g. education and experience), but all of them were teaching technology in compulsory school at the time of the interviews. In order to obtain as representative and varied a selection of informants as possible, the study included both men and women, recently graduated teachers and teachers with many years of experience, teachers both with and without an education in technology, and teachers teaching primary (grades 1-6) and lower secondary (grades 7-9) of compulsory school. Most of them (6) taught grades 4-6. Table 1 presents a summarised description of the teachers.

\section{Data collection}

The ten informants worked in three municipalities. The interviews took place at each informant's workplace and lasted about an hour. The interviews were semi-structured (Kvale 1994) and were based on an interview guide including main questions and supplementary questions. The main questions were about the teacher's experience and personal views of technology education (e.g. What do you find most important for students to learn in the technology education syllabus?; What is the difference between teaching technology and other subjects?; Do you feel secure in teaching technology?), and of the state of the subject in the school (e.g. How is technology taught at your school?; What are the prerequisites?; What do you need to develop technology teaching in your school?) as well as background questions (e.g. teachers' education, interests, in-service training). Throughout the research process the ethical principles for research were followed as customary by informing the participants about the purpose of the interviews and about their right to consent and to discontinue their participation should they wish to. Furthermore, they were informed about their participation being anonymous, and that the data would not be used for anything else than research purposes (Swedish Research Council 2002). The interviews were performed and transcribed in Swedish. Excerpts used in this article have been translated into English by the authors.

Table 1 Presentation of the informants of the study

\begin{tabular}{|c|c|c|c|c|c|}
\hline Name & $\begin{array}{l}\text { Year of } \\
\text { birth }\end{array}$ & $\begin{array}{l}\text { Year of teacher } \\
\text { examination }\end{array}$ & $\begin{array}{l}\text { Teaching } \\
\text { students in grades }\end{array}$ & $\begin{array}{l}\text { Teacher education in } \\
\text { technology }\end{array}$ & $\begin{array}{l}\text { Certification to teach } \\
\text { technology }\end{array}$ \\
\hline Albert & 1971 & 1999 & $4-6$ & No & $\begin{array}{l}\text { Waiting for } \\
\text { certification }\end{array}$ \\
\hline Belinda & 1965 & 2006 & $4-6$ & No & $\begin{array}{l}\text { Waiting for } \\
\text { certification }\end{array}$ \\
\hline Carl & 1984 & 2014 & $7-9$ & Yes & Yes \\
\hline Diana & 1959 & 1999 & $7-9$ & No & Yes \\
\hline Ellen & 1976 & 1999 & $1-3$ & No & No \\
\hline Fiona & 1966 & 2011 & $4-6$ & No & No \\
\hline Greg & 1958 & 1990 & $7-9$ & No & No \\
\hline Harold & 1973 & 1996 & $4-6$ & Yes & Yes \\
\hline Irene & 1964 & 2001 & $4-6$ & Yes & Yes \\
\hline Jenny & 1971 & 1996 & $4-6$ & Yes & Yes \\
\hline
\end{tabular}




\section{Data analysis}

The interviews were transcribed and subsequently analysed, coded and categorised. All of this was done in Swedish. The method of analysis was qualitative and hermeneutic, using thematic analysis in line with how Braun and Clarke (2006) describe the method in six steps. We employ the framework of teachers' attitude (S. I. van Aalderen-Smeets et al. 2012) in the thematic analysis, to answer the research question. The analysis thus included both deductive and inductive stages. The initial two steps were (1) to familiarise ourselves with the data, which included repeated reading of the entire dataset; and (2) to generate initial codes, which meant that any text section relating to the research question was labelled with a descriptive code. Each labelled text section contained approximately two to ten sentences. These two steps were performed inductively, to find comprehensive patterns in the data. The next step (3) was to generate themes, which first of all meant sorting the codes into a hierarchical order. The themes were then generated deductively in the light of the framework of primary teachers' attitudes since the framework included theoretical concepts with a clear connection to our research question. At this stage, therefore, themes relating to teachers' perceived control stood out as particularly interesting to highlight. The subsequent step, (4) review themes, meant revising and refining themes in order to minimise overlap between them. The next step (5) thus consisted of defining and naming themes and sub-themes where it was found that they included aspects of self-efficacy and context dependency in accordance with the attitude framework (see Fig. 2). The final step (6) was to compile exemplary data and quotes to exemplify the themes. The excerpts should be seen as representative examples of the themes, not as quantitative representations.

Fig. 2 The themes and subthemes obtained from the thematic analysis
Attitudes towards teaching Technology

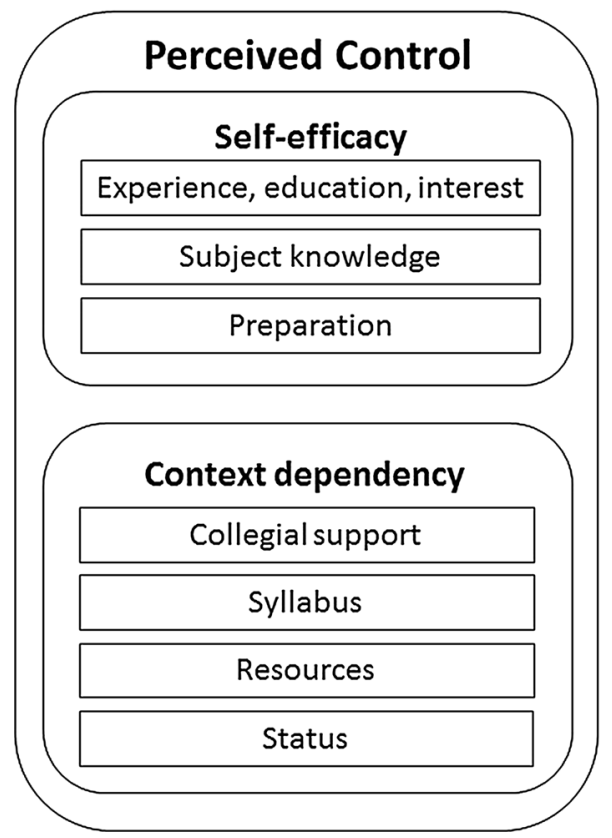


In the interviews, there are no questions directly about the concept of attitude. Attitudes are rather construed by the researchers from the teachers' statements, as in steps three to five above. In some cases, it is obvious that the teachers give voice to attitudes and in other cases it is when the material is decoded by the researchers that attitudes appear. Context dependency is identified when attitudes appear in a situation of perceived external control, for example, "it is more difficult to teach technology because we don't have books" (Albert). Likewise, self-efficacy is recognised when attitudes are apparent in situations concerning perceived internal control in a valuating way, for example, "I think it is easier to teach technology, I am more into it, I know what to do" (Jenny). Several aspects (subthemes) of attitude were identified in this study, and sometimes different sub-themes appeared in the same sentence.

The teachers were not analysed and described one by one, and, therefore, the result is a collective total picture of how these ten teachers together picture technology teaching. The result is thus the researchers' interpretation of the interviewed teachers' perceptions and attitudes on a collective level. The ten interviews constitute a limited data set, but, as we show, it is enough to achieve data saturation and validate our themes. Our results can, in a strict sense, only be seen as representative of the ten interviewed teachers, but we hope to generate an intersubjective understanding of technology teachers' attitudes through them. That is, the results of this study point to possible attitudes that technology teachers may have, particularly concerning perceived control, even beyond the Swedish context (Cutcliffe and McKenna 1999).

\section{Results}

Overall, the teachers spoke positively about the subject of technology and technology education; "It is the subject I enjoy teaching most" (Carl) and "It is an important subject in the school, to be able to understand the world around us." (Greg). The teachers described technology education as an important subject, and they were also in general pleased to teach it.

\section{Self-efficacy}

The analysis resulted in themes related to high and low self-efficacy among the teachers. A teacher could express both high self-efficacy and low self-efficacy in relation to different aspects of technology education.

\section{Experience, education and interest}

Experience, education and interest seemed to be connected to high self-efficacy, according to our interpretation of the teachers' statements in this study. Furthermore, these three aspects seemed to be linked, according to the way the teachers talked about them. Experience, education and interest in technology education and technology, appeared to give teachers knowledge and security in their teaching.

Experience made the teachers prepared for questions from the students and for different situations in the classroom. Jenny described technology education as being easier than the teaching of other subjects, because of her teaching experience. She said that she was both skilled and had a solid basis in technology education. Diana, on the other hand, described 
technology as a wide field of knowledge, and she had control of only a rather small part of it, thus expressing low self-efficacy. This was, she said, because of her lack of knowledge. She therefore described herself as being careful in her teaching and trying to restrict the students to asking questions about the part of the field of technology that she felt comfortable in. She had not studied technology as part of her teacher education. She did, however, consider herself more experienced at the time of the interviews than 5 years before:

Experience makes a big difference [...]. It is in here [points to her head]. [...] You know in advance what questions can be asked, where the student gets stuck and so on, it is experience. (Diana)

Like Diana, Fiona was not educated in technology education either, but she had education in mathematics and she talked about how this had given her experience of and familiarity with the content and structure of the syllabus. Furthermore, she explained that the lack of education and experience in technology teaching affected her in grading her students in technology: "I will be cautious when I set the grades, probably because I don't have the experience [of technology education]". Later she continued talking about the subjects in which she was not educated:

I have not really dug into that syllabus [technology] in the same way as I do in maths, because I have so many credits in maths. Still I believe that I have kept to the [technology] syllabus and I have studied examples of assessment, so I do have a solid basis. But somehow it still feels better to be a bit careful... (Fiona)

Some of the teachers who were educated in technology thought that the amount of technology education they had was not enough. They expressed opinions that pointed to the fact that their self-efficacy in teaching depended on their own personal interest. Harold described himself as a person interested in technology, and he thought that this interest made his teaching better and more inspiring: "Then I can bring many points of view into the teaching, which is not something you can do in other subjects that you aren't that interested in". Jenny pictured it like this:

What things made me a good technology teacher were probably the things I studied myself, my life as well as what I had learned, read and created. Sure, the education was... I got a basis, but that is not what I lean on, it is the other [my life and what I studied myself].

Jenny was educated in technology, and said that she felt "incredibly secure in technology education". She further explained that the more you know about a subject and the more you like a subject, the better teacher you will be, if you dare to try. She compared technology to English, and explained that she would not be a very skilful English teacher: "If I taught English, I wouldn't be the same pedagogue as I am when I teach technology".

Irene was also educated in technology and was very confident and described her own skills and knowledge in some areas of technology education. She said, for example, "I can tinker, I know how things work. When a student asks how a propeller shaft or something like that works, I can explain it. I feel confident in it!" It is thus very clear that her selfefficacy in teaching was affected by her own knowledge and skills concerning the various aspects of the subject content.

The teachers' attitudes to technology teaching included their perceived lack of capability and security. Diana described her situation when she started to teach technology like this: 
At first, I did not want to [teach technology]. If you are insecure, you don't want to, right? A good thing is that we have parallel classes and different teachers, so we cooperate a lot; we have the same pedagogical plans, the same material and so on. You get a lot of help.

In the interview, she said that nowadays she was the one helping her colleagues. Even though she was more secure today than she was when she started to teach technology, she was still "much more secure in the other subjects than in technology". Fiona also described feeling more insecure in technology teaching than in other subjects. She explained that she did not know if she was teaching at the right level or if she made technology education too easy for her students. When it came to such questions, she felt more secure in striking the right balance in the other subjects that she taught. Neither Diana nor Fiona had studied technology as part of their teacher education.

Overall, non-educated technology teachers gave the impression of being more insecure than educated teachers. Nevertheless, educated as well as non-educated teachers could show high self-efficacy in one area of technology education and low self-efficacy in another area. A strong interest in technology seems generally to lead to higher selfefficacy.

\section{Subject knowledge}

The teacher's subject knowledge emerged as an area of self-efficacy. Some of the teachers stated that there were gaps of knowledge that they needed to fill, and Albert was one of them. He mentioned technological systems and electricity as two areas of technology education that he would like to know more about in order to become more secure in his teaching. Carl thought that he was not very skilled in construction and building, but he believed that he could handle it and manage it anyway because, according to him, these areas are not central parts of technology education. Furthermore, he explained that he has good knowledge of other aspects of the subject, such as computers, electronics and information technology.

Fiona sometimes asked herself if she was focusing on the right things in technology education, and if she was teaching at the right level. She gave one example from when she was teaching about "simple machines" - the lever, the screw, the wedge, the inclined plane, the pulley, and the wheel — and she took her students outside to try the machines in the schoolyard: "I was thinking, 'Did I do the right things? [...] Was this valuable? It was so time-consuming. Why didn't we just read about it in a book? Sometimes it is difficult to find the right level'". In sum, Fiona knew that the simple machines are central to technology education, but she did not have enough subject knowledge and she felt insecure about finding the right level of knowledge for the students.

In sum, the teachers in this study gave examples of how lack of subject knowledge in some parts of technology seems to be a source to low self-efficacy.

\section{Preparation}

Diana's view was that she did not want her students to notice when she was not skilled enough or lacked knowledge. Therefore, she said, she read a lot and always wanted to be prepared. Jenny and Irene described their teaching in a similar way. Neither of them would come to class without being prepared. Jenny also read a lot and she "would never start a teaching sequence without being in control". Irene tried out her teaching at home with her 
own sons. Fiona described how she first tried at home, before doing something in class, and explained that this was a way for her to handle the subject matter that she was unsure about.

Just like Diana, Jenny, Irene and Fiona, Ellen found a way to compensate for her low self-efficacy. Ellen had no formal technology teacher education and described herself to be "totally non-technical". She stated that her students asked a good deal of questions that she could not answer. She tried to solve this problem by discussing with the students, and by googling and reading, and sometimes she had to get back to them the following week to answer their questions. Ellen said that she felt insecure in situations like this, but now, on the whole, she felt secure in teaching technology: "I feel that I have enough knowledge, otherwise I would not teach it".

Preparation of various kinds thus seems to be a way for teachers to compensate for low self-efficacy, for instance, by googling, reading and rehearsing at home.

\section{Context dependency}

The analysis of the interviews resulted in four sub-themes for the attitude component context dependency. The sub-themes characterise teachers' attitudes towards technology education in terms of different kinds of external factors that they perceive as influencing their control of the teaching situation. The sub-theme collegial support consisted of the interviewed teachers' experiences of their teaching being affected positively by support from colleagues and negatively by having too little time and opportunities for discussing technology education with colleagues. The sub-theme syllabus included the teachers' perceptions of how the syllabus made their teaching easier or more difficult. The sub-theme resources included experiences of the classroom situation in general and availability of resources such as textbooks, money and materials and how the resources had a facilitating or obstructing effect on teachers' technology teaching. The last sub-theme was status, which concerned the perceived effects of positive or negative status of the subject in school. In the following, each of the four sub-themes of the context dependency theme will be described in more detail.

\section{Collegial support}

The sub-theme collegial support emerged in contexts where teachers described a lack of time. In some cases, it also emerged in working situations without other colleagues with whom to discuss technology. The teachers argued that meeting colleagues for discussing and developing the subject was something that contributed positively to their teaching. Jenny described how she and her two colleagues cooperated and gave each other tips. Belinda said that in her former workplace, they discussed the syllabus of technology in depth and gave each other examples of how to interpret it. The collegial discussion made her confident in her teaching and she felt that she could bring that knowledge to her new workplace. Most of the interviewed teachers, however, described a lack of time and opportunities for collegial support and development of the subject. Harold did not have time or the opportunity to meet others and exchange ideas and discuss dilemmas around technology teaching. He expressed it like this:

I need more time to talk to the other technology teachers [...] we have asked for cross-disciplinary teaching for a long time, and we will try to arrange that, but there is a lack of time. We need to discuss together primarily in our school. It would have 
been nice to get clarification and directions from above, but we won't get that, it's obvious. It is all about your own interpretation [...] that is difficult. (Harold)

In the interviews, teachers talked about a need for meeting other technology teachers, the meetings are necessary to discuss the subject in general or, more specifically, assessment in technology. Carl expressed it like this: "My greatest need is to sit down and talk to other technology teachers about assessment".

\section{Syllabus}

Some of the interviewed teachers talked about how the syllabus positively affected their teaching. They described the syllabus as easy to understand and live up to, and as having been written in a clear way. Jenny expressed this by comparing the syllabus of technology to the other subjects:

If you compare it with others, it is easy and clear. I think I like it. The core content is kind of tangible, the abilities [mentioned in the syllabus] are a bit like in science, but more distinct. I like it!

Harold expressed a similar view and explained: "It is the syllabus that is easiest to fulfil [...] it is not lengthy and is quite easy to understand. It is the one I am most comfortable with". Here he was comparing technology to the other subjects he taught.

One negative attitude expressed, on the other hand, was that the syllabus was difficult to understand. For example, Albert wanted to have a local teaching plan for technology, which would help him to understand the syllabus and make it easier for the students to assimilate it. He described using such a supportive strategy to overcome problems with the syllabus in his other subject, crafts/sloyd, where he had developed a local plan in collaboration with other sloyd teachers. A second negative attitude towards the influence of the syllabus on teaching was that the syllabus was pointless and that using it did not have a positive effect on technology education. For example, Greg explained that he did not read the syllabus and that he thought there was overall too much focus on the syllabus and criteria for grading. He was an experienced teacher but he had only been teaching the subject of technology for a few months, and he explained that he preferred focusing on learning in a wider perspective than just focusing on the syllabus of technology.

\section{Resources}

The lack of resources ended up affecting the teaching negatively, according to all of the teachers in this study. The lack of resources was perceived as affecting the teachers' working situation and made it more difficult for them to teach, because they had to put time and effort into other tasks than teaching. There were three distinct areas related to resources as external factors of teaching; the classroom, textbooks, and materials and money.

The teachers in this study taught technology in different types of classrooms which had different pros and cons; the crafts/sloyd classroom, the arts classroom, the science classroom, the pupils' "general" home classroom, a classroom designed for technology education, or a combined technology and science classroom. The teachers were positive about having a classroom designed for technology, because this made technology teaching easier for them. Some teachers needed to move between different classrooms, which seemed to have a negative effect on their technology teaching, that is, it was limiting not being able to 
stay in the same classroom. They explained that they spent a lot of time carrying materials between classrooms. Another consequence of the lack of a proper technology classroom was the lack of space for storing the pupils' constructions and materials between the lessons. The design of the classroom could also restrict the teaching when it came to materials. Diana, for example, taught technology in a science classroom and she could not let the pupils use wood and saws in her classroom. Instead, she encouraged them to use other kinds of materials, like board. The preconditions of the classroom definitely affected the teachers' attitude to their teaching, which was reflected by Harold who expressed frustrated feelings about his classroom: "We would need new group activity rooms, classrooms with room for everyone, to have room for the material, to avoid hauling. It is tiresome! It is not enjoyable!"

Some of the interviewed teachers said there was a lack of technology textbooks in their school. Carl thought that the lack of textbooks made the teaching in technology more difficult than teaching other subjects. He said; "Of course it is more difficult, because we don't have technology textbooks at my school". Belinda explained that she had to choose between buying textbooks or construction materials for her classes.

The teachers expressed negative feelings around not having enough tools and construction materials. One explanation for the lack of materials for teaching technology was a low budget for the subject. Carl explained that there had been a low involvement among the technology teachers in his school to organise and buy materials because of a lack of interest among the other technology teachers. He explained that they taught many subjects, and technology was the least favourable among them. He clarified it like this: "There is probably no one who really embraced the subject of technology. [...] It has just been there in the background..." Belinda solved the problem by asking the pupils to bring construction materials from home. Harold and Jenny both used Lego in their teaching. Neither of them had enough Lego for their classes, which forced them to let the pupils work in pairs or in groups of three. Belinda's reflection about the lack of materials was:

You have to reinvent the wheel time after time, because there isn't that much of material to use. I should need a classroom for laboratory work. Now I have to borrow the sloyd classroom. [...] Also, [the students] could bring materials from home, you can recycle things from home.

\section{Status}

The status of the subject of technology affects the technology teaching by giving the subject low attention compared to other subjects, according to the teachers. It can be seen in the organisation of the working situation of the teachers, for example, how the school management and the teachers themselves plan and organise meetings, and if they set up time and space for technology. When the teachers talked about the status of the subject, they talked about technology teachers, other teachers, and their attitudes in general, rather than about their own personal attitude. It is possible that there were some teachers in this study who had personal attitudes like that, even though they did not express them in the interviews. One explanation for this could be that it is easier to talk about others' views and attitudes than your own.

The informants described technology as a subject in the shadow of other subjects, not because they themselves believed so, but because they said others did. Some of the teachers felt that the subject of technology had a low status in their schools, and others 
believed that the subject had a low status in general, but not in their own schools. The lower status was shown at teacher meetings, according to Carl:

Well, technology is in the background, so it is. The other teachers who teach technology also teach science and mathematics. Sometimes, when we are supposed to meet and talk about the subject of technology, we talk about science or mathematics instead. [...] That is a shame. [...] [technology] does not get as much time as the other subjects.

Belinda and Harold thought that technology teaching had a low status in general and they talked about teachers' lack of interest, knowledge and education, their ideas of technology as a difficult subject to teach, and lack of support from the principal, as possible explanations. Albert described this as a vicious circle: the teachers had little knowledge, which led them to think that the subject was less important which also led to a low budget, and therefore they could not teach because of the lack of materials and books. Belinda and Carl both communicated about how a lower status could depend on the lack of national tests, which took place in science and mathematics. Diana strongly emphasised that in her school all subjects had the same status and were treated the same way. At the same time, she did not portray her own situation like this. She described technology education in a different way than science education and said that they planned to teach technology at the end of the year to make the situation easier for the pupils. She expressed it like this:

In the ninth grade they have national tests [for instance, in science], and then it is much easier if the students do not have as many theoretical tasks as in other subjects. They just come to class to potter with this and that. And we do a study visit and some assignment [instead of tests] and in that way we don't burden the students too much at the end of the school year. This is how we have planned all the technology teaching at the end of the school year.

Overall, the teachers in the study perceived that context dependency affected their teaching in different forms. The teachers expressed this both regarding physical context, e.g. in the form of lack of enough books and less visible context e.g. less attention compared to other subjects.

\section{Discussion}

This study contributes to a development of the attitude framework (van Aalderen-Smeets et al. 2012) in the sense that the sub-themes adapt the framework for technology education settings. The results indicate that perceived control is a part of attitude that is central among technology teachers and affects their teaching in technology education. Perceived internal control can be seen in three sub-themes: (1) Experience, education and interest, (2) subject knowledge and (3) preparation. All of the three sub-themes include aspects of high and low self-efficacy. Context dependency can be seen as four sub-themes; (1) collegial support, (2) syllabus, (3) resources and (4) status.

The context dependency aspect of perceived control is the most obvious to observe, both for researchers and teachers, since context dependency aspects are concrete and directly affect the daily teaching, for example, if there is a classroom for technology education or if there are enough textbooks and materials. Self-efficacy, however, is not so obvious, but might be just as important. 
The ways the interviewed teachers experienced the influence of these aspects of attitude, are in this study separated into sub-themes to make them easier to recognise and discuss. In reality, these sub-themes interact and appear in different ways and in different combinations among different teachers. The focus in this study is on a collective answer to the research question, not on an analysis of each teacher separately. Furthermore, there might be additional sub-themes that have not been observed in this study.

\section{Self-efficacy}

All of the 10 teachers in this study expressed an overall positive attitude to the subject of technology. Since they all participated voluntarily, we believe it is conceivable that these ten were more positive towards technology education than technology teachers are in general. Teachers with a low interest in technology education are probably more likely to decline an interview. The participants' overall positive attitude is revealed in how they expressed opinions about how they enjoyed technology education or considered it to be an important school subject. Still, when it comes to the aspects of attitude that are examined in this study, more negative attitudes were stated as well.

We know from previous studies that high self-efficacy has a positive effect on teaching, e.g. regarding students' achievement (Caprara et al. 2006; Tschannen-Moran et al. 1998) and the instructional quality of the teacher (Holzberger et al. 2013). An overall finding of this study is that self-efficacy among the teachers varies, which means that the degree of self-efficacy depends on factors such as experience, education, interest, subject content, time for preparation, or the actual teaching situation. The quantity of skills a teacher has may not be crucial, according to Bandura: "In short, perceived self-efficacy is concerned not with the number of skills you have, but with what you believe you can do with what you have under a variety of circumstances" (Bandura 1997, p. 37). Regarding the results of this study, self-efficacy can be high, low, or a mix of both for one teacher, but from the general patterns that emerged from the teacher interviews high or low self-efficacy seems to be related to technology teacher education but also to experience and personal interest in technology.

The results further show that teachers find strategies to deal with their insecurity and low self-efficacy by reading and practising at home and generally by being thorough in preparation. Since preparation takes time, it will limit what the teacher will teach.

Even though the aim of this study is not to compare teachers trained in technology with those who are not, some differences still seem to exist. Among the interviewed teachers, the most insecure ones seemed to be those without teacher education in technology, such as Diana and Fiona who confessed that they were more secure in other subjects where they had teacher education, than in technology. The importance of well-educated technology teachers is shown even in other studies, e.g. for the development of the subject of technology (Jones et al. 2013) and the interest of the students (Mattsson 2005). Nordlöf et al. (2017) conclude that the odds of having a positive attitude to technology and technology teaching increase about five times if the teacher is qualified in technology education. Furthermore, there are also higher odds of having a positive attitude if the teacher has participated in in-service training. When teachers' perceptions of STEM are studied, the findings show that teachers' personal knowledge and understanding of STEM are connected to effectiveness in the classroom (Bell 2016). A Swedish study (Hartell et al. 2015) also shows that teachers without technology teacher education are more unsure about how to teach and assess their students. 
In this study, the teachers with a technology teacher education stated that their selfefficacy came from their own interest in technology, from their everyday life. Here we see some similarities to well-developed individual interest, which is discussed by Svenningsson et al. (2016) and Hidi and Renninger (2006) concerning students attitudes. A teacher can have high self-efficacy as well as low self-efficacy related to different parts or aspects of technology education, regardless of whether we include educated or non-educated teachers. Holroyd and Harlen (1996) argue that lack of confidence affects the teaching and makes the teachers concentrate less on aspects of teaching that they have low confidence in. Diana gives an example of this when she explains how she tries to keep the students within the range of technology education that she feels comfortable in. In a British STEM-context, Design and technology teachers who lack confidence similarly avoid risktaking and thereby they limit the breadth of technology education they provide (Bell 2016).

\section{Context dependency}

The teachers stated that their teaching was also affected by external factors, but mostly negative attitudes concerning these factors appeared in the interviews. As early as 1988, a Swedish doctoral thesis (Andersson 1988) showed that there are various external obstacles to technology education as perceived by technology teachers. At that time, technology had recently been introduced as a mandatory subject in Swedish schools and most teachers did not have much experience or education regarding technology education, especially those teaching grades 1-6 (Andersson 1988). The teachers then experienced lack of time, textbooks, material and classrooms for technology education. Almost 30 years later, the current study shows similar results. A lack of material and non-functional classrooms was also seen as a general problem among both studied teachers in a case study by Blomdahl (2007). She examined some frame factors in technology education in her thesis, which was a case study of two technology teachers and their teaching context. Frame factors are similar to contextual or external factors; economic, social and geographic factors affecting a school, but they also include pedagogical and administrative factors that boost or limit the development of the educational processes in the school (e.g. Dahllöf 1973; Lundgren 1972).

The interviewed teachers believed that having collegial support from other technology teachers is important. In New Zealand, teachers experienced similar difficulties in technology education as in this study, because there was a lack of regular meetings for technology teachers, and furthermore, there was a lack of senior teachers to support the new ones (Almutairi 2009). A study from Australian secondary schools, where the implementation of mechatronics is studied, emphasises the need for time for organisation, planning and opportunities for collegial networking and meetings (Nicholas and $\mathrm{Ng} 2012$ ). There are probably different explanations for the lack of collegial support in our study.

Swedish teachers are obligated to follow the syllabus in their teaching, although there is always room for each teacher's own interpretation of the syllabus, for instance, regarding lesson planning, assessment and grading. In the interviews, we can see that the teachers differed in the extent to which they adapted the syllabus. One particularly interesting finding is that teachers educated in technology believed that it was easier to understand and interpret the syllabus, and for them the syllabus was a positive influence on the teaching, while non-educated teachers said they had more problems understanding and adapting the syllabus. Overall, however, for some of the teachers in this study the syllabus was a document that helped them in their teaching, and for others it was a document that was difficult to understand and manage. This finding confirms previous research outcomes in 
New Zealand in connection to the implementation of their technology curriculum. The New Zealand teachers experienced both positive and negative attitudes towards the curriculum. Some found it to be user-friendly but a smaller group wanted to make changes, and among them a popular change was to make the curriculum simpler to understand (Jones et al. 2004).

In a previous study Bjurulf (2008) shows that the classroom affects the content of technology education. She says that the classroom and its equipment signal what kind of education could be carried out there, mainly "practical" or "theoretical" teaching. Furthermore, she claims that teaching technology in a classroom that is furnished and equipped for other subjects might imply that technology is less important, since the classroom is not adapted for technology education. In this study, resources in the form of books, material and money, and the classroom situation affect the teaching directly and in a practical way, according to the teachers, mostly by limiting the teachers in their work situation. For example, both Harold and Jenny said that it was the availability of Lego that determined whether the students could work in pairs or individually. The lack of books, materials and space for storing the students' work are external factors that affect teachers' attitudes even in previous research (Blomdahl 2007). In New Zealand, similar findings have been discussed as areas of difficulty in technology education, in the form of lack of equipment (Jones et al. 2004) and insufficient funding (Almutairi 2009). In our study we can see that the lack of resources drove the teachers to put a lot of effort and time into trying to find solutions to practical problems, such as storing or finding material, instead of teaching the subject. For example, Diana explained how they could not use the building material they wanted in a science classroom, and other teachers in this study had no room for storing the students' work or for keeping teaching materials in a home classroom. The lack of resources, in turn, led to more negative attitudes to technology education.

In Sweden, technology has some obvious associations to science; therefore, when teachers talk about status, they probably compare technology to the science subjects; physics, biology and chemistry. For example, at the time of the data collection, the subject of technology shared 800 teaching hours throughout compulsory school with the science subjects (chemistry, biology and physics). Furthermore, it is common that the same teacher teaches science and technology subjects, but it is also common that the same teacher teaches sloyd and technology.

The status of the subject is not as easy to grasp in the interviews as the availability of resources for teaching and colleagues to work together with, probably because it is not as easy to grasp as physical resources, either for teachers, headmasters or researchers. Still, the status of technology can be construed from the material throughout, even though it is not always clearly expressed. None of the teachers said that they prioritised the subject of technology less than they prioritised other subjects, but it was sometimes evident that they themselves treated the subject differently or that the leadership of the school did. Diana was a good example of this. She pointed out that all subjects were equal, but in the next sentence she explained that they taught technology at the end of the school year when the students were tired. They did what was seen as the core subjects first. In a British study (Bell et al. 2016), where primary school teachers gave their perceptions of subject knowledge and breadth and quality of their work, a similar result was shown in an excerpt from a participant:

Schools do Design and technology as a treat at the end of a unit of work if applicable, and it is not respected as a standalone subject in the curriculum (Bell et al. p. 7). 
There seemed to be a general view among the interviewed teachers that the subject of technology had to be "fun" or "joyful" for the students. This made the status lower compared to other subjects like science, which was seen as difficult (e.g. Osborne et al. 2003). Teachers in this study explained that they did not think that technology had a low status in their particular school, but they believed that the subject had a low status in other schools and that the subject overall had a low status. The national tests have become central in Swedish schools, as an important way to measure results and set grades, and some teachers put a lot of effort into the tests since they are a way to verify the students' knowledge. Since technology is not included in the tests, it could be construed as a less important subject.

One aspect of status is that the subject is less prioritised than science subjects, which can be seen in the interviews as well as in a report from the Swedish schools inspectorate (Skolinspektionen 2014). Recently, the Swedish government proposed to give the subject of technology, as well as the science subjects, $200 \mathrm{~h}$ of teaching time each, instead of sharing $800 \mathrm{~h}$ together with the science subjects. This will hopefully improve the status of the subject and is in line with the result of Nordlöf et al. (2017) who found a fixed amount of teaching hours to be a predictor of a positive attitude to technology teaching among technology teachers. This, and other contextual factors, may therefore lead to a more positive attitude towards technology education among teachers.

\section{Conclusion}

This study has contributed, first of all, to a refined adaptation of the attitude framework (van Aalderen-Smeets et al. 2012) to technology education. More specifically, the component of perceived control has been expanded and adjusted to technology education by adding sub-components that may reflect a more fine-grained view of technology teachers' attitudes.

Secondly, this study discusses how technology teachers perceive the extent to which they can control their teaching, as a component of their attitude to technology education. Context dependency can both limit and boost the teachers, but overall there are negative attitudes concerning context dependency, because of a lack of support that hinders the teaching. Teachers educated in technology education seem to have advantages in relation to technology teaching, but still they sometimes experience negative attitudes in the field of perceived control. The subject of technology is broad and in continuous development in Swedish schools, which may account for this. This may also be a reason why teachers have a high self-efficacy in certain aspects of the subject domain and low self-efficacy in others. Even teachers with a teaching qualification in technology education do not necessarily have skills and knowledge concerning all aspects of the subject. This, in turn, is a good argument for technology teachers being given continuous support and in-service training. Self-efficacy comes from experience, education and interest, according to the teachers in this study, and previously Nordlöf et al. (2017) have shown that education makes teachers more likely to be positive towards their subject.

Thirdly, the results raise questions about possible similarities to teacher experiences in the 1980s. It is interesting to note that teachers today experience similar thoughts about and attitudes towards the status and resources of technology education as teachers did when technology was introduced as a mandatory subject. Efforts have been made since the 80's to strengthen the subject and the teachers, which have had some positive results. However, 
our results indicate that there is still more to be done to boost technology education and its primary representatives, the technology teachers.

Some implications of this study are to reserve resources for technology education in the form of time, money, and teacher education, thereby supporting teachers in controlling contextual and internal factors that affect their teaching. This is especially important if there is an intention for the subject to develop in new directions, since teachers tend to stay in their "comfort zones" and teach more of the aspects of the subject they are familiar with.

Open Access This article is distributed under the terms of the Creative Commons Attribution 4.0 International License (http://creativecommons.org/licenses/by/4.0/), which permits unrestricted use, distribution, and reproduction in any medium, provided you give appropriate credit to the original author(s) and the source, provide a link to the Creative Commons license, and indicate if changes were made.

\section{References}

Ajzen, I. (2001). Nature and operation of attitudes. Annual Review of Psychology, 52(1), 27-58.

Almutairi, A. (2009). Teachers' perceptions of technology and technology education, years 7 to 10. (Thesis), Auckland University of Technology.

Andersson, Y. (1988). Teknikämnet på grundskolans mellanstadium: Department of Education and Psychology, Linköping University.

Asma, L., Van Der Molen, J. W., \& van Aalderen-Smeets, S. (2011). Primary teachers' attitudes towards science and technology professional development for primary teachers in science and technology (pp. 89-105). Berlin: Springer.

Bandura, A. (1997). Self-efficacy: The exercise of control. Basingstoke: W. H. Freeman.

Bell, D. (2016). The reality of STEM education, design and technology teachers' perceptions: A phenomenographic study. International Journal of Technology and Design Education, 26(1), 61-79.

Bell, D., Martin, M., Woff, D., \& McLain, M. (2016). Primary design and technology: Perceptions and practice Paper presented at the PATT-32.

Bjurulf, V. (2008). Teknikämnets gestaltningar: En studie av lärares arbete med skolämnet teknik: Karlstad: Estetisk-filosofiska fakulteten. Pedagogiskt arbete: Karlstads universitet.

Blomdahl, E. (2007). Teknik i skolan: En studie av teknikundervisning för yngre skolbarn. Stockholm: HLS förlag.

Braun, V., \& Clarke, V. (2006). Using thematic analysis in psychology. Qualitative Research in Psychology, 3(2), 77-101.

Breckler, S. J. (1984). Empirical validation of affect, behavior, and cognition as distinct components of attitude. Journal of Personality and Social Psychology, 47(6), 1191.

Caprara, G. V., Barbaranelli, C., Steca, P., \& Malone, P. S. (2006). Teachers' self-efficacy beliefs as determinants of job satisfaction and students' academic achievement: A study at the school level. Journal of School Psychology, 44(6), 473-490.

Cutcliffe, J. R., \& McKenna, H. P. (1999). Establishing the credibility of qualitative research findings: The plot thickens. Journal of Advanced Nursing, 30(2), 374-380.

Dahllöf, U. (1973). The curriculum development system in Sweden: Some comments on present trends and problems. International Review of Education, 19(2), 218-231.

Hartell, E., Gumaelius, L., \& Svärdh, J. (2015). Investigating technology teachers' self-efficacy on assessment. International Journal of Technology and Design Education, 25(3), 321-337. https://doi. org/10.1007/s10798-014-9285-9.

Hidi, S., \& Renninger, K. A. (2006). The four-phase model of interest development. Educational Psychologist, 41(2), 111-127.

Holroyd, C., \& Harlen, W. (1996). Primary teachers' confidence about teaching science and technology. Research Papers in Education, 11(3), 323-335.

Holzberger, D., Philipp, A., \& Kunter, M. (2013). How teachers' self-efficacy is related to instructional quality: A longitudinal analysis. Journal of Educational Psychology, 105(3), 774.

Jones, A., Buntting, C., \& de Vries, M. J. (2013). The developing field of technology education: A review to look forward. International Journal of Technology and Design Education, 23(2), 191-212. 
Jones, A., Harlow, A., \& Cowie, B. (2004). New Zealand teachers' experiences in implementing the technology curriculum. International Journal of Technology and Design Education, 14(2), 101-119.

Korur, F., Vargas, R. V., \& Serrano, N. T. (2016). Attitude toward science teaching of Spanish and Turkish in-service elementary teachers: Multi-group confirmatory factor analysis. Eurasia Journal of Mathematics, Science \& Technology Education, 12(2), 303-320.

Kvale, S. (1994). InterViews: An introduction to qualitative research interviewing. Thousand Oaks: Sage Publications Inc.

Lumpe, A. T., Haney, J. J., \& Czerniak, C. M. (2000). Assessing teachers' beliefs about their science teaching context. Journal of Research in Science Teaching, 37(3), 275-292.

Lundgren, U. P. (1972). Frame factors and the teaching process: A contribution to curriculum theory and theory on teaching.

Mattsson, G. (2005). Lärares teknikdidaktiska kompetens och dess betydelse för elevers teknikintresse. Nordina, 01(01), 31-42.

Nicholas, H., \& Ng, W. (2012). Factors influencing the uptake of a mechatronics curriculum initiative in five Australian secondary schools. International Journal of Technology and Design Education, 22(1), 65-90. https://doi.org/10.1007/s10798-010-9138-0.

Nordlöf, C., Höst, G. E., \& Hallström, J. (2017). Swedish technology teachers' attitudes to their subject and its teaching. Research in Science \& Technological Education, 35(2), 195-214.

Osborne, J., Simon, S., \& Collins, S. (2003). Attitudes towards Science: A Review of the Literature and Its Implications. International Journal of Science Education, 25(9), 1049-1079.

Rohaan, E. J., Taconis, R., \& Jochems, W. M. G. (2008). Reviewing the relations between teachers' knowledge and pupils' attitude in the field of primary technology education. International Journal of Technology and Design Education, 20(1), 15. https://doi.org/10.1007/s10798-008-9055-7.

Skolinspektionen. (2014). Teknik—gör det osynliga synligt (04). Retrieved from Stockholm: http://www. skolinspektionen.se/Documents/publikationssok/granskningsrapporter/kvalitetsgranskningar/2014/ teknik/kvalgr-teknik-slutrapport.pdf.

Skolverket. (2011). Curriculum for the compulsory school system, the pre-school class and the leisure-time centre 2011 Retrieved from http://www.skolverket.se/publikationer?id=2575.

Skolverket. (2017). Siris Grundskolan - personalstatistik med behörighet - per ämne och kategori. Retrieved from http://siris.skolverket.se/reports/rwservlet?cmdkey=common\&notgeo=\&p_verksamhetsar= 2015\&p_omgang=1\&report=personal_amne2\&p_skolkod=\&lankod=\&kommunkod=\&p_hman= $00 \&$ p_niva $=$ S\&p_amne $=\&$ p_verksform $=11$.

Svenningsson, J., Hultén, M., \& Hallström, J. (2016). Understanding attitude measurement: Exploring meaning and use of the PATT short questionnaire. International Journal of Technology and Design Education, 1-17.

Swedish Research Council, V. (2002). Forskningsetiska principer inom humanistisk-samhällsvetenskaplig forskning: Vetenskapsrådet Stockholm.

Tschannen-Moran, M., Hoy, A. W., \& Hoy, W. K. (1998). Teacher efficacy: Its meaning and measure. Review of Educational Research, 68(2), 202-248.

van Aalderen-Smeets, S. I., Walma van der Molen, J. H., \& Asma, L. J. (2012). Primary teachers' attitudes toward science: A new theoretical framework. Science Education, 96(1), 158-182. 